\title{
Response of the edamame edible soybean germplasm to Diaporthe phaseolorum, causal agent of soybean stem canker, in Argentina
}

\author{
Raquel Benavidez ${ }^{1}$, Rosanna N. Pioli ${ }^{2}$ \& Eligio N. Morandi ${ }^{3}$ \\ ${ }^{1}$ Cátedra de Mejoramiento Vegetal y Producción de Semillas; ${ }^{2}$ Cátedra de Fitopatología, ${ }^{3}$ Cátedra de Fisiología Vegetal, \\ Facultad de Ciencias Agrarias, Universidad Nacional de Rosario, C.C. 14, 2125 Zavalla, Santa Fe, Argentina
}

Author for correspondence: Raquel Benavidez, e-mail: rbenavid@unr.edu.ar

\begin{abstract}
The objective was to evaluate the reaction of introduced edamame edible soybean germplasm against Soybean stem canker (SSC), caused by Diaporthe phaseolorum var. meridionalis $(\mathrm{Dpm})$ and D. phaseolorum var. caulivora (Dpc) in the humid Pampa of Argentina. Thirty edamame genotypes were evaluated in greenhouse conditions using an experimental design in blocks with two replications, over two years. Edamame germplasm showed a different degree of resistance to five Diaporthe phaseolorum isolates. The existence of interand intra-varietal differences in Dpm and Dpc virulence were also found, verifying that genes conferring resistance to Dpm and Dpc are different. This study showed that genetic variability does exist in edamame germplasm and would be useful in breeding for resistance or tolerance.
\end{abstract}

Keywords: Glycine max, evaluation of resistance, plant breeding.

\section{RESUMO}

Resposta de germoplasma de edamame a Diaporthe phaseolorum, agente causal de cancro da haste da soja

O objetivo deste trabalho foi avaliar o comportamento da primeira coleção do germoplasma introduzido de edamame sobre resistência/susceptibilidade ao Cancro da Haste da Soja (SSC), causado por Diaporthe phaseolorum var. meridionalis (Dpm) e D. phaseolorum var. caulivora (Dpc) no Pampa Húmido Argentino. Trinta genótipos de edamame foram avaliados em casa de vegetação e o delineamento experimental foi o de blocos completos com duas repetições. O germoplasma de edamame mostrou diferentes níveis de resistência a cinco isolados de Diaporthe phaseolorum. Determinaram-se diferenças na virulência de Dpm e Dpc, verificando assim que os genes que conferem resistência a Dpm e Dpc são diferentes. Este trabalho demonstra que existe variabilidade genética no germoplasma de edamame e será útil no melhoramento para resistência e tolerância.

Palavras chave: Glycine max, cancro da haste, avaliação da resistência, melhoramento.

Edamame is a particular kind of soybean, Glycine $\max (\mathrm{L}$.$) Merr., used for human consumption due to its$ special taste and flavor and it is an extensively cultivated field crop. Edamame presents bright green pods and seeds, bigger than grain soybean. Pods are harvested at maximum seed expansion, when seeds fill locule (R6 growth stage, Fehr \& Caviness, 1977); and they are consumed fresh or frozen when still green. The quality of the commercial edamame is defined by parameters of pods and seeds. Disease damage is of paramount importance to determine edamame commercial grades, since pathogens may affect the production, quality and commercialization standards, reducing the crop value. Disease symptoms affect product appearance and decrease its commercial value; healthy pods influence edamame consumers positively. Moreover, chemical control must be avoided or reduced to a minimum in a product for direct human consumption like edamame. In this context, genetic resistance or tolerance to pathogen affecting pods and seed quality and yield must be seriously considered in breeding of edamame edible soybean.

In the humid Pampa of Argentina, diseases cause important soybean yield losses in the core of soybean producing area. Diaporthe - Phomopsis constitutes a genetically diverse fungal complex, which produces different pathologies in soybean such as pod and stem blight, seed decay and soybean stem canker (SSC) (Fernández et al., 1999). An outbreak of SSC was reported in this area (Pioli et al., 1997) and in northwest Argentina in the 19961997 growing season, causing severe damage reaching 70$100 \%$ in some fields (Ploper et al., 1999), mainly due to the wide diffusion of susceptible cultivars, high inoculum, and predisposing weather conditions (Wrather et al., 1997). Because of this, SSC resistance has been included as an obligatory requirement for a new cultivar release.

$\mathrm{SSC}$ resistance was attributed to four dominant independent genes with Mendelian inheritance: $R d c 1$ and $R d c 2$, present in cultivar Tracy-M (Kilen \& Hartwig, 1987); 
$R d c 3$, present in cultivar Crockett, and $R d c 4$ in cultivar Dowling (Bowers et al., 1993) and in cultivar Hutcheson (Tyler, 1996). Additionally, in the humid Pampa of Argentina, the co-existence of both $D$. phaseolorum (Cooke \& Ellis) Sacc. varieties, i.e. $D$. phaseolorum var. meridionalis and $D$. phaseolorum var. caulivora Athow \& Caldwell (Dpm and Dpc, respectively) was reported (Pioli et al., 2001), and the resistance genes were re-named as $R d m 1$ to $R d m 4$ based on published evidence that the resistance genes to Dpm were not effective against Dpc isolates (Pioli et al., 2003; Pioli \& Morandi, 2006; Chiesa et al., 2009). The SSC disease may significantly affect pod and seeds, constituting a risk of high impact on the visual appearance of edamame's fresh product and on seed production. Therefore, it was necessary to evaluate introduced edamame germplasm for interaction with SSC causal agents. This knowledge will be important for breeding programs to obtain edamame cultivars adapted to local agro-ecological conditions. The objective of this study was to evaluate resistance of introduced edamame germplasm in the humid Pampa of Argentina to D. phaseolorum var. meridionalis and $D$. phaseolorum var. caulivora.

Dpm and Dpc local isolates were collected from different agro-ecological regions and were morphologically and molecularly identified (Pioli et al., 2003) according to the techniques proposed by Fernández \& Hanlin (1996). The isolates identified by our group were deposited in the Culture Collection of CEREMIC (Centro de Referencia de Micología, Fac. Cs. Bioquímicas y Farmacia, UNR). Three Dpm isolates were used for soybean stem canker pathogenicity assays in greenhouse conditions: CE 109 (San Justo, Santa Fe, Ar), CE111 (Barrancas, Santa Fe, Ar) and CE112 (Clarke, Santa Fe, Ar), and the Dpc isolates used were: CE 116 (Oliveros, Santa Fe, Ar) and DPCB-IT (USA). The isolates were cultured on potato glucose agar medium (PGA) $2 \%$ acidified with lactic acid $0.2 \%$, and incubated at $26 \pm 1{ }^{\circ} \mathrm{C}$ in darkness. When developed, previously to the experiment, isolates were inoculated on susceptible control (cultivar RA702) and re-isolated from it to verify their virulence condition (Pioli et al., 2003).

Inoculation technique of SSC causal agents: hypocotyls of seedlings at the fully expanded trifoliate leaf stage (12 to 14 days old) were inoculated introducing a portion of mycelium $(1.5 \times 1.5 \mathrm{~mm})$ into a wound, which was immediately covered with petroleum jelly to avoid dehydration. Control seedlings were similarly wounded but no mycelia were applied. For the first $72 \mathrm{~h}$ after inoculation, inoculated and control seedlings were kept in high humidity atmosphere using a transparent plastic coverage in natural photoperiodic conditions (Pioli et al., 2003). Meanwhile the temperature range (day-night) was between $27 \pm 3^{\circ} \mathrm{C}$ and 18 $\pm 3^{\circ} \mathrm{C}$, respectively.

In the first pathogenicity assay, the local Dpm isolate, CE 109, was evaluated in 29 edamame introductions, in local edamame cultivar Agata (G 10 x G 47) (Benavidez et al.,, 2002), and in grain soybean cultivars Tracy-M, Crockett, Dowling, Hutcheson (used as Dpm resistant controls), and RA 702 (Dpm susceptible control). The experimental design was in blocks with two replications. Twelve plants per genotype-isolate interaction and per replication were inoculated. The results obtained in this first pathogenicity trial were considered in carrying out the second one.

The second pathogenicity assay was performed to detect resistance to both $D$. phaseolorum varieties (Dpm and Dpc) SSC causal agents. Edamame germoplasm with resistant reaction to $\mathrm{CE} 109 \mathrm{Dpm}$ isolate, edamame genotype G 47 control (Agata parent) and grain soybean controls were inoculated with the CE 111 and CE 112 local isolates of Dpm and with the DPCB-IT (USA isolate) and CE 116 (local isolate) of Dpc. The experimental design was in blocks with two replications. Nine plants per genotypeisolate interaction and per replication were inoculated. Both pathogenicity assays were carried out during the spring of two different years.

Germplasm phenotypic responses were visually evaluated through disease symptoms observed at 30 days after inoculation (dai). To calculate the percentage dead plant (\%DP), a value of 1 was assigned to each dead plant, a value of 0.5 to each plant displaying stem canker symptoms or foliar discoloration and a value of 0 for healthy plant. The $\%$ DP was calculated as the proportion of plants that were either dead or showed any SSC symptoms out of the total number of plants observed in each interaction (Pioli et al., 2003). According to the \%DP, plant-pathogen interactions were classified as resistant $=0$ to $14.9 \% \mathrm{DP}$; moderately susceptible $=15$ to $49.9 \%$ DP; susceptible $=50$ to $84.9 \%$ DP and highly susceptible $=85$ to $100 \%$ DP. This scale was based on previous studies (Yorinori, 1996; Rupe et al., 1999; Pioli et al., 2003), and allowed to characterize the germplasm reaction.

In the first assay, the 30 edamame genotypes showed a range of response against the local CE 109 isolate of Dpm. Ten out of 30 genotypes (33.3\%) showed resistant interaction (i.e. $<14.9 \%$ DP), 19 genotypes $(63.3 \%)$ showed susceptible interaction (between 15 and $49.9 \%$ DP), one genotype (3.3\%) was susceptible (between 50.0 and $84.9 \%$ DP). As expected, resistant control cultivars Tracy M, Crockett, Hutcheson and Dowling showed incompatible interaction (0 to $11.1 \%$ DP), and susceptible control RA 702 was highly susceptible (100.0\% DP) (Table 1).

In the second assay, edamame germplasms $\mathrm{G} 7, \mathrm{G} 8$, G 10, G 17, G 20, G 25, G 44, and Agata (resistant to the CE 109 isolate) plus G 47 (Agata parent) were further evaluated with isolates of Dpm and Dpc. When inoculated with Dpm isolates, all nine genotypes were resistant (0 to $5.8 \% \mathrm{DP}$ ) to the CE 112 isolate, while eight out of nine genotypes were also resistant to the CE 111 isolate (0 to $11.1 \% \mathrm{DP})$. Agata showed a slightly higher value than the resistance threshold when inoculated with CE 111 isolate $(16.7 \%$ DP). RA 702 (susceptible control) was highly susceptible to CE 111 and susceptible to CE 112 isolates (88.2 to 83.3 $\%$ DP, respectively). As expected, resistant controls showed incompatible reactions (0 to $9.1 \%$ DP, Table 1 ). 
TABLE 1 - Percent dead plants of edamame edible soybean germplasm at 30 days after inoculation with isolates of Diaporthe phaseolorum var. meridionalis (Dpm) and Diaphorte. phaseolorum var. caulivora (Dpc) in greenhouse conditions in two assays

\begin{tabular}{|c|c|c|c|c|c|}
\hline \multirow{4}{*}{$\begin{array}{l}\text { Edamame germplasm } \\
\text { and codes }\end{array}$} & \multicolumn{5}{|c|}{$\%$ Dead plant / isolate } \\
\hline & \multicolumn{2}{|l|}{ First assay } & \multicolumn{2}{|c|}{ Second assay } & \\
\hline & \multirow{2}{*}{$\frac{\text { Dpm }}{\text { CE } 109}$} & \multicolumn{2}{|c|}{ Dpm } & \multicolumn{2}{|c|}{ Dpc } \\
\hline & & CE 111 & CE 112 & DPCB-IT & CE 116 \\
\hline AGS 186 (G 3) & 25.0 & - & - & - & - \\
\hline AGS 181 (G 4) & 32.6 & - & - & - & - \\
\hline AGS 188 (G 5) & 34.1 & - & - & - & - \\
\hline AGS 189 (G 6) & 28.3 & - & - & - & - \\
\hline AGS 190 (G 7) & 0.0 & 8.0 & 0.0 & 94.4 & 19.4 \\
\hline AGS 191 (G 8) & 9.5 & 5.0 & 0.0 & 97.2 & 25.0 \\
\hline KVS 124-KS3 (G 9) & 38.7 & - & - & - & - \\
\hline GC $84126($ G 10$)$ & 0.0 & 0.0 & 0.0 & 94.4 & 69.4 \\
\hline GC 841127 (G 11) & 26.5 & - & - & - & - \\
\hline GC $84126-12$ (G 12) & 40.0 & - & - & - & - \\
\hline GC 84128 (G 13) & 18.7 & - & - & - & - \\
\hline GC 84129 (G 14) & 20.0 & - & - & - & - \\
\hline GC 84136 (G 15) & 13.3 & - & - & - & - \\
\hline Sapporo Midori (G 16) & 33.3 & - & - & - & - \\
\hline Kitanosuzu (G 17) & 7.9 & 11.1 & 5.8 & 91.7 & 26.5 \\
\hline Late Giant (G 18) & 22.9 & - & - & - & - \\
\hline Kanrich (G 19) & 31.2 & - & - & - & - \\
\hline Tomahomare (G 20) & 2.3 & 0.0 & 0.0 & 58.8 & 41.7 \\
\hline Natto (G 21) & 27.5 & - & - & - & - \\
\hline PI 84-4590 (G 22) & 43.5 & - & - & - & - \\
\hline PI 157440 (G 23) & 47.9 & - & - & - & - \\
\hline PI 408251 (G 25) & 4.5 & 0.0 & 0.0 & 66.7 & 28.1 \\
\hline PI 86023 (G 26) & 29.2 & - & - & - & - \\
\hline Wase-Hakucho (G 41) & 15.2 & - & - & - & - \\
\hline MikawashimaChusei (G 42) & 20.5 & - & - & - & - \\
\hline WaseshirogeHouseki (G 43) & 50.0 & - & - & - & - \\
\hline Wase-Midori (G 44) & 4.5 & 2.9 & 5.5 & 50.0 & 41.7 \\
\hline Tanba Kenjou Kuro (G 45) & 0.0 & - & - & - & - \\
\hline G 47 & 18.2 & 0.0 & 0.0 & 36.1 & 13.9 \\
\hline Agata & 12.0 & 16.7 & 5.6 & 61.1 & 47.2 \\
\hline $\mathrm{CV}$ & 6.67 & 12.3 & 15.0 & 3.14 & 4.9 \\
\hline \multicolumn{6}{|l|}{ Control grain cvs. ( $R d m$ genes) } \\
\hline Tracy M (Rdm1, Rdm2) & 0.0 & 0.0 & 0.0 & 100.0 & 53.1 \\
\hline Crockett $(R d m 3)$ & 8.3 & 0.0 & 0.0 & 88.8 & 47.1 \\
\hline Hutcheson $(R d m 4)$ & 5.5 & 2.8 & 2.8 & 85.3 & 11.1 \\
\hline Dowling (Rdm4) & 11.1 & 9.1 & 0.0 & 33.3 & 20.0 \\
\hline RA 702 (without $R d m$ genes) & 100.0 & 88.2 & 83.3 & 66.7 & 22.2 \\
\hline $\mathrm{CV}$ & 11.2 & 16.2 & 19.4 & 4.43 & 4.81 \\
\hline
\end{tabular}

When inoculated with the DPCB-IT isolate of Dpc, all the edamame germplasms, previously evaluated as resistant to Dpm, were moderately susceptible to highly susceptible (36.1 to $97.2 \%$ DP). Remarkably susceptible (RA 702) and resistant (Tracy M, Crockett, Hutcheson, and Dowling) control cultivars for Dpm showed different susceptibility degrees with DPCB-IT isolate (33.3 to $100 \%$ DP) (Table 1). When assayed with the local CE 116 isolate of Dpc, G 47 was the only resistant edamame genotype
(13.9\% DP), while all others were up to very susceptible (19.4 to $69.4 \%$ DP). Control cvs. RA 702, Tracy, Crockett, and Dowling were also susceptible, ranging from 20.0 to $53.1 \%$ DP. However, cv. Hutcheson was resistant to the CE 116 isolate (11.1\% DP, Table 1). In general, local isolate CE 116 was less virulent than the USA isolate DPCB-IT to both edamame and control soybean germplasm.

Eight out of 30 introduced germplasms were resistant to the three Dpm isolates evaluated, suggesting that 
Response of the Edamame edible soybean germplasm to Diaporthe phaseolorum...

$R d m$ resistant genes do exist in the edamame germplasm. The control grain genotypes' reaction exhibited similar responses as those previously reported. The evaluation of the introduced edamame germplasm through both assays performed in this work was, in fact, supported by the reproducibility of results obtained for control grain genotypes (Table 1). Remarkably, G 47 was resistant to two Dpm isolates (CE 111 and 112) and to the local Dpc isolate, CE116. This genotype may constitute an important source of bred resistance to both $D$. phaseolorum varieties causing SSC; this is very important, mainly since genes conferring resistance to Dpm do not confer resistance to Dpc (Pioli et al., 2003). Additionally, the results obtained with edamame germplasm extend the existence of inter- and intra-varietal differences in Dpm and Dpc virulence when interacting in edamame background. In general, results showed that edamame germplasm evaluated express variability in their response to SSC causal agents, providing an interesting source of genetic variation for breeding purposes.

\section{ACKNOWLEDGMENTS}

We thank Dr. G. Hartman, for providing the DPCB-IT isolate of $D p c$, and Drs. S. Shanmugasundaram, M. Carrao-Panizzi and Mr. S. Yamazaki for providing edamame genotypes. This research was supported by the Agencia Nacional de Promoción Científica y Tecnológica, Argentina. Projects BID 1201/OC-AR PICT 08-09890 and BID 1728/OC-AR PID 22995-04.

\section{REFERENCES}

Benavidez R, Gosparini CO, Morandi EN (2002) Registration of AGATA soybean. Registro Nacional de Cultivares y Registro Nacional de la Propiedad de Cultivares Res. No 121 Secretaría de Agricultura, Ganadería, Pesca y Alimentación. Argentina.

Bowers GR, Ngeleka K, Smith OD (1993) Inheritance of stem canker resistance in soybean Crockett and Dowling cvs. Crop Science 33:67-70.

Chiesa MA, Pioli RN, Morandi, EN (2009) Specific resistance to soybean stem canker conferred by the Rdm4 locus. Plant Pathology 58:1032-1038.

Fehr, W, Caviness, RH (1977) Stages of soybean development. Special Report 80. Iowa State University Ames, Iowa.
Fehr WR, Caviness CE, Burmood DT, Pennington JS (1971) Stage of development descriptions for soybeans, Glycine max (L.) Merrill. Crop Science 11:929-931.

Fernández FA, Hanlin HT (1996) Morphological and RAPD analyses of Diaporthe phaseolorum from soybean. Mycologia 88:425-440.

Fernández FA, Phillpis DV, Russin JS, Rupe JC (1999) Stem canker. In: Compendium of Soybean Diseases. Fourth edition. Saint Paul MN. APS Press. pp. 33-35.

Kilen TC, Hartwig EE (1987) Identification of single genes controlling resistance to stem canker in soybean. Crop Science 27:220-222.

Pioli RN, Gattusso S, Prado D, Borghi A (1997) Recent outbreak of stem canker (Diaporthe phaseolorum var. meridionalis) of soybean in Santa Fe, Argentina. Plant Disease 81:1215.

Pioli RN, Morandi EN, Bisaro V (2001) First Report of Soybean Stem Canker caused by Diaporthe phaseolorum var. caulivora in Argentina. Plant Disease 85:95.

Pioli RN, Morandi EN, Martínez M, Lucca M, Tozzini A, BisaroV, Hopp E (2003) Morphologic, molecular and pathogenic characterization of Diaporthe phaseolorum variability in the core of soybean producing area of Argentina. Phytopathology 93:136146.

Pioli RN, Morandi EN (2006) Situación del complejo Diaporthe Phomopsis en el cultivo de Soja de Argentina. $3^{\circ}$ Congreso de Soja del Mercosur - Mercosoja- Rosario. Argentina. Compendio de Conferencias, Foros y Workshops. pp. 325-331.

Ploper LD, González V, Galvez MR, Devani M, Salas MG (1999) Outbreak of soybean stem canker in Northwestern Argentina. Proceedings, VI World Soybean Research Conference. Chicago, USA. pp. 615-616.

Rupe JC, Sutton EA, Beckton CM, Gbur EE (1999) Effect of soybean growth stage at the time of inoculation with Diaporthe phaseolorum var. meridionalis on stem canker development and yield. Plant Disease 83:582-586.

Sas Institute (1990) SAS/STAT users guide. Ver.6.12. SAS Inst. Cary NC.

Tyler JM (1996) Characterization of stem canker resistance in Hutcheson soybean. Crop Science 36:591-593.

Wrather JA, Anderson TR, Arsyad DM, Gai J, Ploper LD, PortaPuglia A, Ram HH, Yorinori JT (1997) Soybean disease loss estimates for the Top 10 soybean producing countries in 1994. Plant Disease 811:107-110.

Yorinori JT (1996) Cancro da haste da soja: epidemiologia e controle. Londrina PR. EMBRAPA Soja. Circular Técnica No 14.

TPP 9060 - Received 5 May 2009 - Accepted 18 January 2010 Section Editor: Nilceu R.X. Nazareno 